\title{
Plant-mediated methane and nitrous oxide fluxes from a carex meadow in Poyang Lake during drawdown periods
}

\author{
Qiwu Hu • Jiayan Cai • Bo Yao • Qin Wu • \\ Yeqiao Wang $\cdot$ Xingliang Xu
}

Received: 10 February 2015 / Accepted: 9 November 2015 /Published online: 19 November 2015

(C) Springer International Publishing Switzerland 2015

\begin{abstract}
Aims Plants have been suggested to have significant effects on methane $\left(\mathrm{CH}_{4}\right)$ and nitrous oxide $\left(\mathrm{N}_{2} \mathrm{O}\right)$ fluxes from littoral wetlands, but it remains unclear in subtropical lakes.

Methods We conducted in situ measurement of $\mathrm{CH}_{4}$ and $\mathrm{N}_{2} \mathrm{O}$ fluxes for two years. To distinguish between the effects of shoots and roots, three treatments (i.e., intact plants as control, shoot clipping, and root exclusion) were used. Effects of plant biomass, temperature, and soil moisture on $\mathrm{CH}_{4}$ and $\mathrm{N}_{2} \mathrm{O}$ fluxes were analyzed.

Results The mean ecosystem $\mathrm{CH}_{4}$ emission rate was $36 \mu \mathrm{g} \mathrm{CH} \mathrm{CH}^{-2} \mathrm{~h}^{-1}$ for drying periods, but $8219 \mu \mathrm{g}$ $\mathrm{CH}_{4} \mathrm{~m}^{-2} \mathrm{~h}^{-1}$ for drying-wetting transition periods. $\mathrm{CH}_{4}$
\end{abstract}

Responsible Editor: Ute Skiba.

Electronic supplementary material The online version of this article (doi:10.1007/s11104-015-2733-9) contains supplementary material, which is available to authorized users.

Q. Hu · J. Cai $\cdot$ B. Yao · Q. Wu $\cdot$ Y. Wang

Ministry of Education's Key Laboratory of Poyang Lake Wetland and Watershed Research, Jiangxi Normal University, 99, Ziyang Road, Nanchang 330022, China

\section{Xu $(\bowtie)$}

Key Laboratory of Ecosystem Network Observation and Modelling, Institute of Geographic Sciences and Natural Resources Research, Chinese Academy of Sciences, 11A, Datun Road, Chaoyang District, Beijing 100101, China

e-mail: xuxingl@hotmail.com

Q. Hu · Y. Wang

Department of Natural Resources Science, University of Rhode Island, Kingston, RI 02881, USA fluxes were positively correlated with below-ground and total biomass, but not with above-ground biomass. Clipping did not significantly alter $\mathrm{CH}_{4}$ flux rate, but root exclusion decreased the $\mathrm{CH}_{4}$ flux by $116 \%$ as compared to the control. $\mathrm{N}_{2} \mathrm{O}$ emissions were similar for both the drying and drying-wetting transition periods, with a mean rate of $20 \mu \mathrm{g} \mathrm{N}_{2} \mathrm{O} \mathrm{m}{ }^{-2} \mathrm{~h}^{-1}$. Both clipping and root exclusion significantly increased $\mathrm{N}_{2} \mathrm{O}$ fluxes as compared to the control.

Conclusions There was no significant correlation between $\mathrm{CH}_{4}$ and $\mathrm{N}_{2} \mathrm{O}$ fluxes. Roots dominated plantmediated enhancement in $\mathrm{CH}_{4}$ fluxes, but played almost an equal role as shoots in plant-regulated suppression on $\mathrm{N}_{2} \mathrm{O}$ fluxes in this Carex meadow during drawdown periods.

Keywords Poyang Lake Carex meadow $\cdot \mathrm{CH}_{4} \cdot \mathrm{N}_{2} \mathrm{O}$. Subtropical

\section{Introduction}

Atmospheric concentrations of methane $\left(\mathrm{CH}_{4}\right)$ and nitrous oxide $\left(\mathrm{N}_{2} \mathrm{O}\right)$ have increased by $150 \%$ and $20 \%$, respectively, since pre-industrial times, contributing to more than $25 \%$ of anthropogenic global warming (Forster et al. 2007; IPCC 2013). Global wetlands were estimated to account for a third of the current annual $\mathrm{CH}_{4}$ emissions, and they are the dominant natural source of atmospheric $\mathrm{CH}_{4}$ fluxes and their interannual variability (Bridgham et al. 2013; IPCC 2013). Meanwhile, wetlands are recognized as considerable 
$\mathrm{N}_{2} \mathrm{O}$ emitters with an annual rate of $0.36 \mathrm{~kg} \mathrm{~N}_{2} \mathrm{O}$ $\mathrm{N} \mathrm{ha}^{-1} \mathrm{yr}^{-1}$ (Zhuang et al. 2012). Although high productivity and water-logged conditions make many wetlands significant carbon (C) sinks (Bernal and Mitsch 2012), strong $\mathrm{CH}_{4}$ and $\mathrm{N}_{2} \mathrm{O}$ emissions from wetlands could largely offset these $\mathrm{C}$ sinks. For example, considering $\mathrm{CH}_{4}$ emission, a wetland in the southern Rocky Mountains acted as $\mathrm{C}$ source in each of the testing years from 1996 to 1998 (Wickland et al. 2001). The same results were observed in a subarctic peatland in Northern Sweden (Bäckstrand et al. 2010). Moreover, if the global warming potential (GWP) of $\mathrm{CH}_{4}$ and $\mathrm{N}_{2} \mathrm{O}$ is taken into account, many other wetlands could turn into sources of atmospheric radiative forcing (Whiting and Chanton 2001; Friborg et al. 2003). Hence, it is necessary to integrate both $\mathrm{CH}_{4}$ and $\mathrm{N}_{2} \mathrm{O}$ into assessments for the net greenhouse gas (GHGs) effect from wetlands.

$\mathrm{CH}_{4}$ and $\mathrm{N}_{2} \mathrm{O}$ emissions from wetlands are subjected to a number of biotic and abiotic controls (Jørgensen and Elberling 2012; Bridgham et al. 2013), among which plants are considered to be the major one because they can strongly affect $\mathrm{CH}_{4}$ and $\mathrm{N}_{2} \mathrm{O}$ production, consumption, and transportation (Rückauf et al. 2004; Laanbroek 2010). Plant presence can increase soil $\mathrm{CH}_{4}$ flux by enhancing substrate availability. There is strong evidence showing that $\mathrm{CH}_{4}$ emission is favored by photosynthates in the form of root exudates (King and Reeburgh 2002; Dorodnikov et al. 2011; Ström et al. 2012). The transport of oxygen from shoots to the rhizosphere via aerenchyma can lead to the suppression of methanogenesis and oxidation of $\mathrm{CH}_{4}$ to $\mathrm{CO}_{2}$. Additionally, transport through vascular plants is one of the most available pathways for $\mathrm{CH}_{4}$ emissions from wetlands (Schimel 1995; Bellisario et al. 1999; Ding et al. 2005). Although nitrification and denitrification are the major processes leading to $\mathrm{N}_{2} \mathrm{O}$ emission from soils (Conrad 1996), plants also affect these processes through competition with microbes for mineral N (Cavieres and Badano 2009). In addition, plants can supply microbes with labile substrates and serve as a transport pathway, which may increase $\mathrm{N}_{2} \mathrm{O}$ emissions (Rückauf et al. 2004; Jørgensen et al. 2012). Previous studies have reported increases (Bellisario et al. 1999; Laanbroek 2010) or decreases (Kao-kniffin et al. 2010; Sutton-Grier and Megonigal 2011) of $\mathrm{CH}_{4}$ emission in response to an increase in plant biomass or productivity. The contribution of plant-mediated $\mathrm{CH}_{4}$ flux varied substantially among species and wetland types (Whiting and Chanton 1992; Ding et al. 2005; Dorodnikov et al. 2011). Similarly, lower (Johansson et al. 2003; Maltais-Landry et al. 2009) and higher (Rückauf et al. 2004; Wang et al. 2008) $\mathrm{N}_{2} \mathrm{O}$ emissions have been reported in artificial wetlands with plants, as compared to those without plants. Therefore, the mechanisms describing the effects of plants on $\mathrm{CH}_{4}$ and $\mathrm{N}_{2} \mathrm{O}$ fluxes from wetlands remain unclear. In addition, a full understanding of wetland $\mathrm{CH}_{4}$ and $\mathrm{N}_{2} \mathrm{O}$ emissions requires knowledge about how above- and below-ground compartments of plant community individually affect the fluxes. Distinguishing the specific influence of above- and below-ground parts is a way to better understand the effect of plants on $\mathrm{CH}_{4}$ and $\mathrm{N}_{2} \mathrm{O}$ fluxes.

There are increasing concerns on the relations between GHGs, because these relations could be used to predict one GHG flux based on measurement of another. For instance, significant correlations between $\mathrm{N}_{2} \mathrm{O}$ and $\mathrm{CO}_{2}$ fluxes are observed in many terrestrial ecosystems (Garcia-Montiel et al. 2002; Xu et al. 2008), but little attention has been paid to GHG relations in wetlands. $\mathrm{CH}_{4}$ is produced in anaerobic conditions, whereas $\mathrm{N}_{2} \mathrm{O}$ can also be derived from aerobic nitrification and anaerobic denitrification. Theoretically, denitrification is energetically more favorable as compared to methanogenesis (Conrad 1996; Hedin et al. 1998). Therefore, when $\mathrm{N}_{2} \mathrm{O}$ flux increases, $\mathrm{CH}_{4}$ emission should decrease, and vice versa. This indicates a negative correlation between $\mathrm{N}_{2} \mathrm{O}$ and $\mathrm{CH}_{4}$ might be expected if denitrification is a dominate source of $\mathrm{N}_{2} \mathrm{O}$. The expected correlation between $\mathrm{CH}_{4}$ and $\mathrm{N}_{2} \mathrm{O}$ in the above-ground efflux needs to be proved by profiling below-ground measurements in relation to numerous environmental parameters.

The littoral zones of lakes comprise a biogeochemically active terrestrial-aquatic interface, where organic matter is transferred to the associated lakes, and GHGs are exchanged with the atmosphere (Larmola et al. 2003). Studies have demonstrated that littoral wetlands were 'hot spots' for $\mathrm{CH}_{4}$ and $\mathrm{N}_{2} \mathrm{O}$ emissions (Juutinen et al. 2003a; Wang et al. 2006a, 2006b; Chen et al. 2009). However, most of these studies were concentrated in boreal or cold regions (Larmola et al. 2003; Juutinen et al. 2003a, 2003b; Chen et al. 2009, 2011). Although lake areas in low latitudes are much smaller than in high latitudes, the estimated sediment GHG productions from low latitude lakes were substantially higher than boreal lakes (Marotta et al. 2014). Consequently, the knowledge of $\mathrm{CH}_{4}$ and $\mathrm{N}_{2} \mathrm{O}$ emissions from various littoral wetlands, especially in largely unexplored tropical and subtropical lakes, will help reduce the uncertainty in global wetland $\mathrm{CH}_{4}$ and $\mathrm{N}_{2} \mathrm{O}$ estimation. 
Poyang Lake is the largest subtropical shallow water lake in China. It is characterized by drastic annual and inter-annual water level fluctuation affected by the tributary rivers in the watershed as well as the quantity of water in the Yangtze River. During drawdown periods, the littoral wetlands are dominated by wet Carex meadows that account for approximately $30 \%$ of the total lake area (Hu et al. 2010). Carex meadows experience two growing seasons that occur in the spring and in autumn after the summer flooding (Hu et al. 2010). In recent years, climate change and the operation of the Three Gorges Dam (since 2003) have largely altered the hydrological regime of Poyang Lake, resulting in a reduction of the summer flooding duration and extension of drawdown periods (Zhang et al. 2012). Quantifying GHG fluxes from Carex meadows during drawdown periods will help to advance the understanding of biogeochemical processes in response to ongoing climate warming and hydrological change in this large subtropical lake. We have reported ecosystem respiration and its components in a Carex meadow during the drawdown period in a recent study (Hu et al. 2015). In this study, we evaluated $\mathrm{CH}_{4}$ and $\mathrm{N}_{2} \mathrm{O}$ emissions during drawdown periods, and aimed to determine the effects of above-ground and below-ground compartments of Carex on $\mathrm{CH}_{4}$ and $\mathrm{N}_{2} \mathrm{O}$ fluxes through shoot clipping and root exclusion. We also intended to test the following two hypotheses: (1) there is a negative correlation between $\mathrm{CH}_{4}$ and $\mathrm{N}_{2} \mathrm{O}$ fluxes based on thermodynamics of denitrification and methanogenesis, and (2) the presence of Carex should enhance emissions of $\mathrm{CH}_{4}$ and $\mathrm{N}_{2} \mathrm{O}$ because plants can provide root exudates for microorganisms living in the rhizosphere and increase their activities.

\section{Materials and methods}

Study area

This study was conducted in the Nanji Wetlands National Nature Reserve in the south of Poyang Lake in China. The experimental site is located at latitude $28^{\circ}$ $53^{\prime} 35^{\prime \prime} \mathrm{N}$, longitude $116^{\circ} 19^{\prime} 11^{\prime \prime} \mathrm{E}$ and at an altitude of $15 \mathrm{~m}$ above sea level in Xinjian County, Jiangxi Province, China in the subtropical monsoon climate. The mean annual air temperature is $17.6^{\circ} \mathrm{C}$, with mean January temperature of $5.1{ }^{\circ} \mathrm{C}$ and July temperature of $29.5^{\circ} \mathrm{C}$. The annual precipitation ranges from $1450 \mathrm{~mm}$ to $1550 \mathrm{~mm}$ and most falls from April to June. In the summer rainy season, the Carex meadows are completely inundated, and become part of the large water body of the lake. When the flood recedes in autumn, the Carex meadow emerges. Annual drawdown periods are largely dependent on both local precipitation and the hydrologic regime of the Yangtze River, ranging from 165 to 271 days (Liu et al. 2006; Hu et al. 2010). The drawdown periods could be further separated into drying and drying-wetting transition periods, respectively. For example, the total drawdown duration lasted $195 \mathrm{~d}$ in 2010, where the drying and drying-wetting transition periods were $180 \mathrm{~d}$ and $15 \mathrm{~d}$, respectively. Carex meadows are widely distributed in the Nanji Wetlands National Nature Reserve, and the dominant plant is Carex cinerascens, which covers over $95 \%$ of the meadows, leaving negligible amounts of plant-free soil areas. Other accompanying species include Potentilla limprichtii, Cardamine lyrata, and Polygonum hydropiper. Characterized as meadow soil, the organic horizon is about $15 \mathrm{~cm}$ in depth, and soil horizon (under $15 \mathrm{~cm}$ ) is recognized as the mineral layer. The mean soil organic carbon and total nitrogen at a depth of 0-15 cm are $1.97 \pm 0.22 \%$ and $0.173 \pm 0.017 \%$, respectively. The $\mathrm{pH}$ at a soil depth of $0-30 \mathrm{~cm}$ averaged $5.4 \pm 0.6$. During drawdown periods the soil redox potential (Eh) at a depth of $0-30 \mathrm{~cm}$ averaged $171.7 \pm 16.6 \mathrm{mV}$. Mean water table depth ranged from -30 to $-50 \mathrm{~cm}$ below the soil surface (Hu et al. 2010). More details of this Carex meadow are described in $\mathrm{Hu}$ et al. (2015).

\section{Experimental design}

Three treatments were set in a typical Carex meadow ( $>$ $200 \mathrm{~m}^{2}$ ). The plots with intact plants were used as a control treatment (IP). The plots where the aboveground vegetation was removed were referred to as a shoot clipping treatment (SC). Finally, the root exclusion (RE) treatment was where whole plants were removed in several stages in order to minimize soil disturbance. The distance between plots was approximately $10 \mathrm{~m}$. Plots were initially isolated by trenching a plot boundary, and a square-based stainless steel frame (0.5$\mathrm{m}$ length $\times 0.5-\mathrm{m}$ width $\times 0.4-\mathrm{m}$ depth) was inserted into the soil to prevent encroachment of new roots. Shoots inside the frame were frequently cut at the soil surface and removed until they did not grow again within a twomonth period. There was no new shoot regrowth in the frame after the summer flooding in 2009. With the 
above three treatments we attempted to separate the specific influence of above-ground vegetation (shoots) and roots on $\mathrm{CH}_{4}$ and $\mathrm{N}_{2} \mathrm{O}$ fluxes. The difference between IP and SC treatment represents the effect of above-ground vegetation on $\mathrm{CH}_{4}$ and $\mathrm{N}_{2} \mathrm{O}$ fluxes, while the difference between $\mathrm{SC}$ and $\mathrm{RE}$ treatment indicates the effects of living roots. The decomposition of new dead roots inside the RE plots should contribute to methane production and $\mathrm{N}$ transformation, but these impacts might be less important with time (Hanson et al. 2000; Kuzyakov 2006). Therefore, we used $\mathrm{CH}_{4}$ and $\mathrm{N}_{2} \mathrm{O}$ flux data from the $\mathrm{RE}$ treatment measured after February 2010 to determine the effects of root exclusion on the fluxes, because we found the effects of decomposing roots could be negligible after about 9 months when the trenching plots were completed. The $\mathrm{CO}_{2}$ efflux rate ratio of the $\mathrm{RE}$ treatment to the $\mathrm{SC}$ treatment declined substantially from the previous average of 0.86 to 0.60 in March 2010, and the latter ratio (i.e., the contribution of soil microbial respiration to total soil respiration) was consistent with previous studies and was maintained in the following flux measurement days (Hu et al. 2015).

We clipped above-ground vegetation for the SC treatment one day before each flux measurement. After clipping, plants were allowed to grow until the next clipping. The frames were maintained during the entire flux measurements for IP and RE, but replaced in each growing season to ensure survival of below-ground roots for the SC treatment. The area of each sampling plot was $0.25 \mathrm{~m}^{2}$ and triplicate plots were randomly located for each treatment. Measurements of $\mathrm{CH}_{4}$ and $\mathrm{N}_{2} \mathrm{O}$ fluxes started several days after installation of the base-frame to minimize soil disturbance.

Gas sampling and analysis

$\mathrm{CH}_{4}$ and $\mathrm{N}_{2} \mathrm{O}$ fluxes were measured using static closed chamber techniques during the drawdown periods from May 18, 2009 to June 12, 2011, including 5 plant growing periods: May18 to June 24, 2009; September 27, 2009 to January 20, 2010; February 20 to April 10, 2010; October 9, 2010 to January 20, 2011; and February 20 to June 12, 2011.

The sample chambers were made of thin stainless steel, with a chamber and a base-frame component. The chamber $(0.5 \mathrm{~m} \times 0.5 \mathrm{~m} \times 0.5 \mathrm{~m})$ was equipped with two fans inside the top, powered by a $12-\mathrm{V}$ battery. The base-frame had a groove on the upper side that was filled with water to avoid leakage during sampling. Chamber air was sampled using a $100 \mathrm{ml}$ syringe at time intervals of 0-min, 10-min, 20-min and 30-min. Samples were taken between 9:00 and 11:00 h, two to three times per month. Gas samples were transferred to sampling air bags (Polymer film and aluminum foil) and brought to the laboratory for $\mathrm{CH}_{4}$ and $\mathrm{N}_{2} \mathrm{O}$ analysis using a gas chromatograph (GC; Agilent 4890D, Agilent Technologies). The GC was equipped with a flame-ionization detector (FID) and an electron capture detector (ECD). $\mathrm{CH}_{4}$ was separated from other gases using a $2 \mathrm{~m}$ stainless-steel (inner diameter of $2 \mathrm{~mm}$ ) 13XMS column (60/80 mesh) and was detected by FID. $\mathrm{N}_{2} \mathrm{O}$ was separated using a $1 \mathrm{~m}$ stainless-steel (inner diameter of $2 \mathrm{~mm}$ ) Porapak Q (80/100 mesh) column and was detected by ECD. The FID, ECD and column temperatures were maintained at $200{ }^{\circ} \mathrm{C}, 330^{\circ} \mathrm{C}$ and $55^{\circ} \mathrm{C}$, respectively. High purity nitrogen was used as a carrier gas for FID and ECD systems at a flow rate of 30 and $35 \mathrm{ml} / \mathrm{min}$, respectively. The GC configurations for analyzing $\mathrm{CH}_{4}$ and $\mathrm{N}_{2} \mathrm{O}$ concentrations were according to the method outlined in Wang and Wang (2003), and the flux calculations followed the description of Song et al. (2008). Negative fluxes indicated an uptake of the gas from the atmosphere and positive indicated a release from the ecosystem.

Environmental factors

During gas sampling, ambient air temperature, soil temperature at a depth of $5 \mathrm{~cm}$, and headspace air temperature of sample chambers were measured simultaneously using a portable thermometer (JM624, JinMing Instruments, China). Soil water content at a depth of $10 \mathrm{~cm}$ was determined using a moisture meter (TDR300, Spectrum Technologies, USA). An automatic air temperature meter (HOBO Pro, Onset Company, USA) was employed at the sampling site to record daily air temperature at an interval of $2 \mathrm{~h}$.

Plant biomass was measured by clipping vegetation samples from three representative $0.25-\mathrm{m}^{2}$ areas about every 30 days during the drawdown periods. The first biomass measurements in spring and autumn were conducted in early February and 10 days after the drawdown area emergence, respectively. Plant materials were divided into living and dead parts before they were oven dried at $70{ }^{\circ} \mathrm{C}$ for $48 \mathrm{~h}$ and then weighed. Root biomass was measured by collecting soil samples from depths of $0-40 \mathrm{~cm}$ from three $0.25-\mathrm{m} \times 0.25$-m plots, which were 
co-located with the plot of the above-ground biomass measurement. The main parameters for distinguishing live from dead roots were the root color, the elasticity of the roots, and the presence of cortex and lateral roots (Dong 1997; Robertson et al. 1999). We combined the above parameters to decide whether a root should be regarded as live or dead. We collected all live roots with a diameter less than $2 \mathrm{~mm}$. Following this standard procedure, the accuracy of root biomass differentiation reached a confidence level of $95 \%$ and the expected error probability of the end values was less than $P<0.05$. However, it is difficult to completely distinguish between live and dead roots and minor errors may have occurred for small-sized roots.

\section{Data analysis}

We excluded outliers when building correlations between $\mathrm{CH}_{4}$ and $\mathrm{N}_{2} \mathrm{O}$ fluxes and for the comparison of $\mathrm{CH}_{4}$ flux among the three treatments. NPP was estimated as the sum of the above-ground and below-ground NPP, and NEP was calculated as the difference between NPP and the total soil $\mathrm{C}$ emission as heterotrophic respiration, which was published in $\mathrm{Hu}$ et al. (2015) (Table 1). To correlate with plant biomass, GHG fluxes measured at the dates of plant samplings $(n=18)$ were used.

\section{Statistical analysis}

One-way ANOVA and paired-t tests were used to test $\mathrm{CH}_{4}$ and $\mathrm{N}_{2} \mathrm{O}$ flux differences among the three treatments. Linear regression models were used to describe the relations between fluxes and temperature, moisture and plant biomass. Data analysis and plotting were processed using SigmaPlot 10.0 (SPSS Inc., Chicago, USA). All statistical analysis was performed using SPSS 11.5 (SPSS Inc., Chicago, USA). All differences were considered statistically significant when $P<0.05$.

\section{Results}

$\mathrm{CH}_{4}$ and $\mathrm{N}_{2} \mathrm{O}$ fluxes

During the drying periods of 2009 to $2011, \mathrm{CH}_{4}$ fluxes from IP, SC and RE treatments showed similar temporal variability. Fluxes reached the maximum at the peak of growing periods and the minimum occurred in January when plants were nearly dormant (Fig. 1b). Over the entire measurement period, $\mathrm{CH}_{4}$ emissions prevailed. $\mathrm{CH}_{4}$ uptakes were observed in all three treatments from the end of November to January when air temperature was lower than $10{ }^{\circ} \mathrm{C}$ and soil moisture content was about $55 \%$. The $\mathrm{CH}_{4}$ flux rates ranged from -128 to $230 \mu \mathrm{g} \mathrm{CH}_{4} \mathrm{~m}^{-2} \mathrm{~h}^{-1}$ for the IP treatment, but -81 to $154 \mu \mathrm{g} \mathrm{CH}_{4} \mathrm{~m}^{-2} \mathrm{~h}^{-1}$ for the SC treatment and -174 to $233 \mu \mathrm{g} \mathrm{CH}_{4} \mathrm{~m}^{-2} \mathrm{~h}^{-1}$ for the RE treatment, respectively. Two extreme $\mathrm{CH}_{4}$ emission events were observed during the soil drying-wetting transition periods. The flux rates were 16,961, 19,157 and 10,925 $\mu \mathrm{g} \mathrm{CH}_{4} \mathrm{~m}^{-2} \mathrm{~h}^{-1}$ for IP, SC and RE treatments, respectively, on June 14, 2009 before summer flooding. Similarly, the counterparts were 3287,3074 and $1708 \mu \mathrm{g} \mathrm{CH}_{4} \mathrm{~m}^{-2} \mathrm{~h}^{-1}$ on October 9, 2010 after summer flooding. $\mathrm{CH}_{4}$ fluxes showed no significant difference among the three treatments $(P>0.05)$. On average, the ecosystem $\mathrm{CH}_{4}$ emission rate was $36 \mu \mathrm{g} \mathrm{CH} \mathrm{CH}^{-2} \mathrm{~h}^{-1}$ for drying periods, but $8219 \mu \mathrm{g} \mathrm{CH} \mathrm{Cm}^{-2} \mathrm{~h}^{-1}$ for drying-wetting transition periods.

$\mathrm{N}_{2} \mathrm{O}$ fluxes from the three treatments also showed clear temporal variability, with higher flux rates occurring in soil drying-wetting transition periods after flooding (Fig. 1c). The flux rates varied from 2 to $66 \mu \mathrm{g} \mathrm{N} \mathrm{N} \mathrm{m}^{-2} \mathrm{~h}^{-1}$ for the IP treatment, but -9 to $132 \mu \mathrm{g} \mathrm{N}_{2} \mathrm{O} \mathrm{m}^{-2} \mathrm{~h}^{-1}$ for the SC treatment and 1 to $395 \mu \mathrm{g} \mathrm{N}_{2} \mathrm{O} \mathrm{m}^{-2} \mathrm{~h}^{-1}$ for the RE treatment, respectively. The mean ecosystem $\mathrm{N}_{2} \mathrm{O}$ emission rate was $20 \mu \mathrm{g} \mathrm{N} \mathrm{N}_{2} \mathrm{O}$ $\mathrm{m}^{-2} \mathrm{~h}^{-1}$ during the drawdown periods. $\mathrm{N}_{2} \mathrm{O}$ flux rates significantly differed among the three treatments $(\mathrm{F}=24.1, P<0.01)$. The mean $\mathrm{N}_{2} \mathrm{O}$ flux rate of the $\mathrm{RE}$ treatment was almost five times higher than the IP treatment, and more than two times higher than the SC treatment. There were no significant correlations between $\mathrm{CH}_{4}$ and $\mathrm{N}_{2} \mathrm{O}$ fluxes from the three treatments (Fig. 2).

Effects of temperature and soil moisture on $\mathrm{CH}_{4}$ and $\mathrm{N}_{2} \mathrm{O}$ fluxes

During drying periods, $\mathrm{CH}_{4}$ flux rates of the three treatments were positively correlated with both air and soil temperatures (Fig. S1). Changes in air temperature could explain $42 \%$ to $44 \%$ of the variation in $\mathrm{CH}_{4}$ fluxes (Fig. S1A-C). By comparison, $43-47 \%$ of $\mathrm{CH}_{4}$ flux variability could be explained by changes in soil temperature at a depth of $5 \mathrm{~cm}$ (Fig. S1D-F). $\mathrm{N}_{2} \mathrm{O}$ fluxes from all three treatments were not correlated with air 


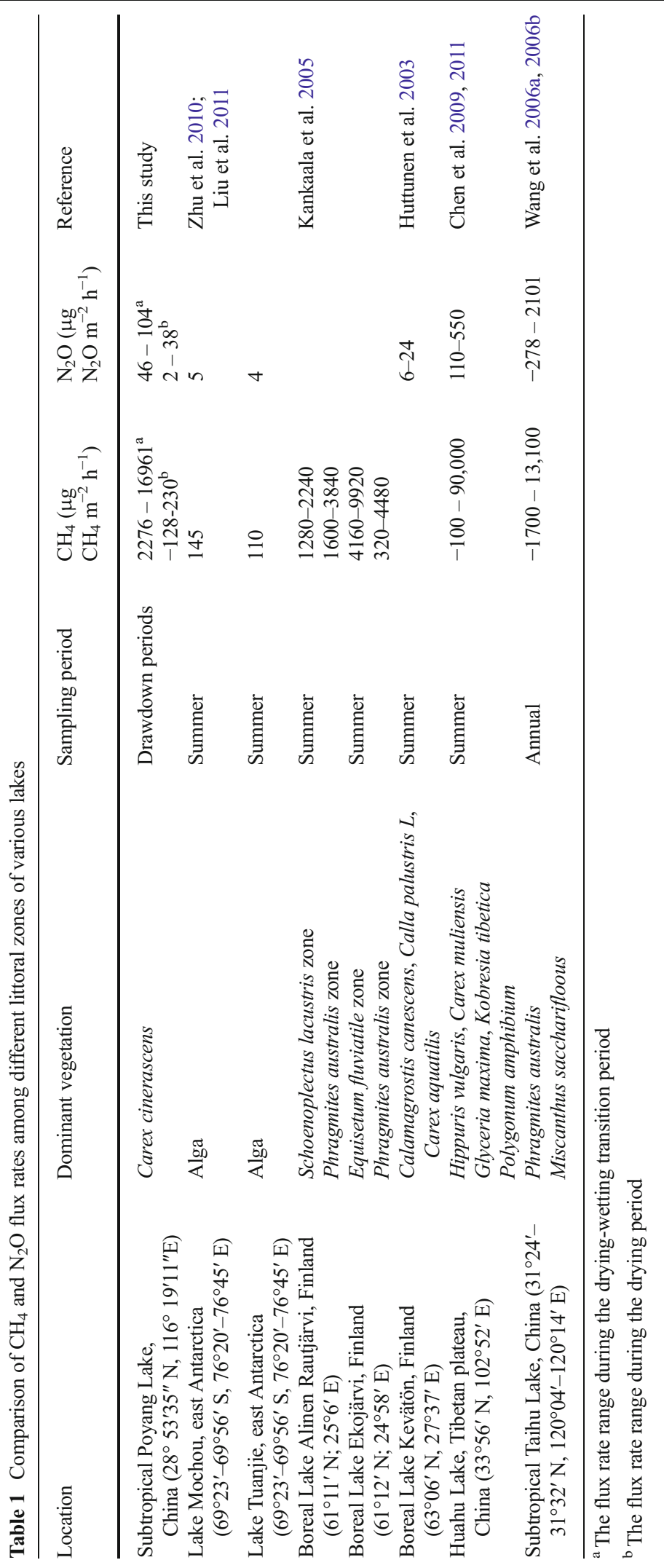


Fig. 1 Temporal variations of air temperature $(A T)$ and soil moisture $(S M)$ (a), $\mathrm{CH}_{4}$ fluxes (b), $\mathrm{N}_{2} \mathrm{O}$ fluxes (c) from the control treatment, intact plants $(I P)$, removal of the aboveground vegetation by clipping $(S C)$ and root exclusion $(R E)$ treatments in the Carex meadow. The flux values are presented as mean $\pm \mathrm{SD}$ of three replicates

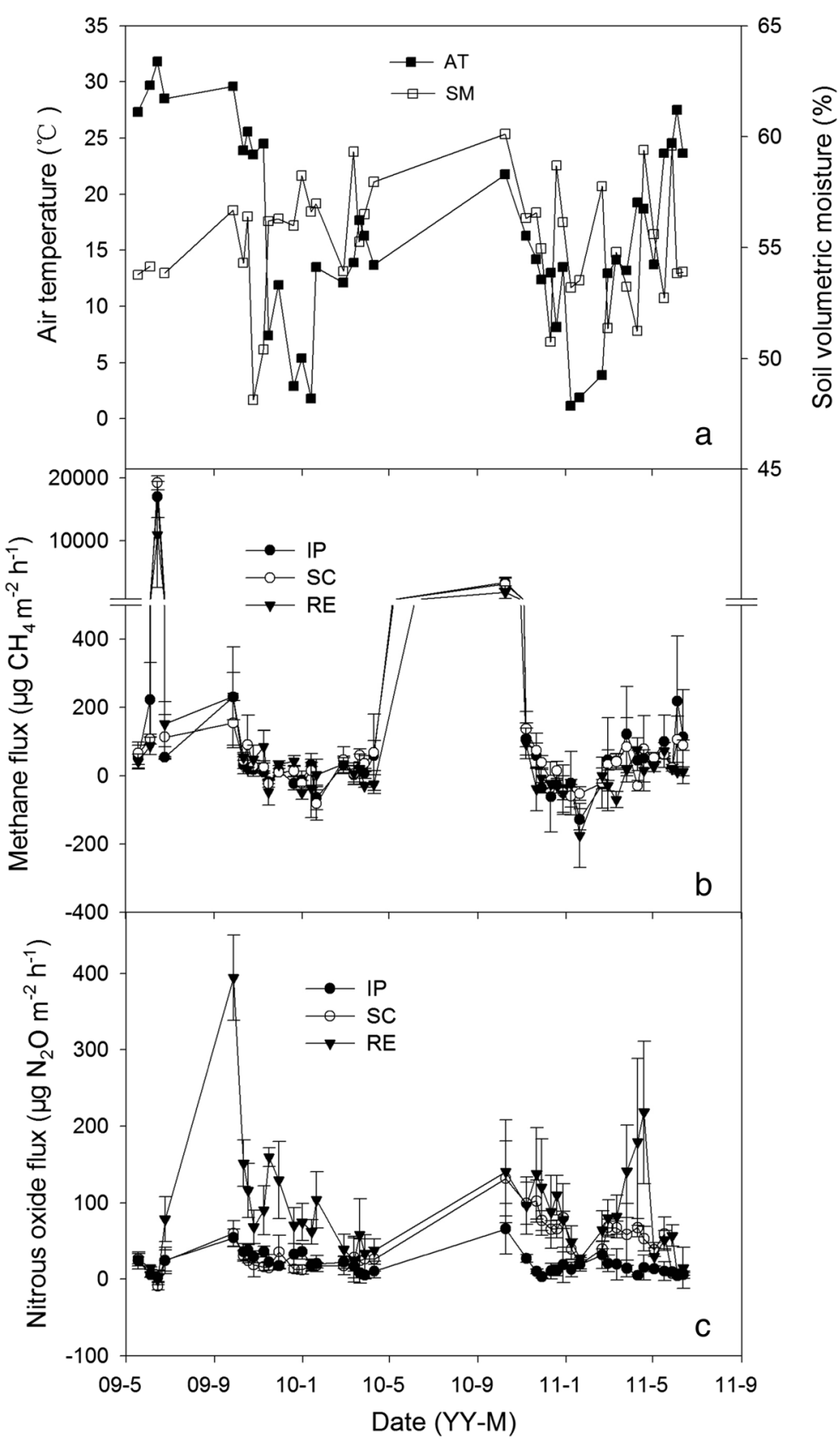

temperature or soil temperature (Fig. S2). In addition, there was no significant correlation between soil moisture at the top $0-10 \mathrm{~cm}$ and $\mathrm{CH}_{4}$ and $\mathrm{N}_{2} \mathrm{O}$ flux rates from the three treatments (Fig. S3).

Effects of plant biomass on $\mathrm{CH}_{4}$ and $\mathrm{N}_{2} \mathrm{O}$ fluxes

$\mathrm{CH}_{4}$ fluxes from IP and SC treatments were positively correlated to below-ground and total biomass, but not to above-ground biomass (Fig. 3a-c). Changes in belowground biomass could explain $37 \%$ and $44 \%$ of the variation in $\mathrm{CH}_{4}$ fluxes from IP and $\mathrm{SC}$ treatments, respectively (Fig. 3b). By contrast, negative correlations were observed between $\mathrm{N}_{2} \mathrm{O}$ fluxes and above-ground and total biomass in the same two treatments (Fig. 3d, f). Changes in above-ground biomass accounted for $28 \%$ and $30 \%$ of $\mathrm{N}_{2} \mathrm{O}$ flux variability from IP and $\mathrm{SC}$ treatments, respectively (Fig. 3d). 


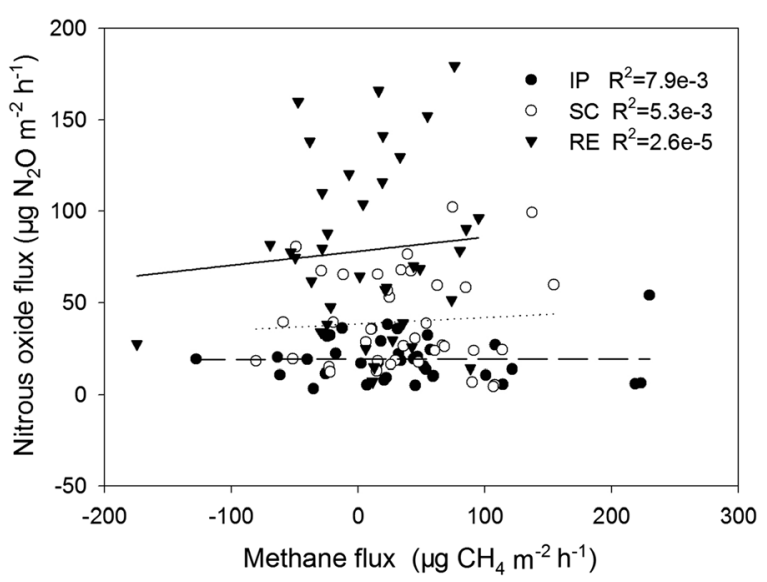

Fig. 2 The relationship between $\mathrm{CH}_{4}$ and $\mathrm{N}_{2} \mathrm{O}$ fluxes from the control treatment, intact plants $(I P)$, removal of the above-ground vegetation by clipping $(S C)$ and root exclusion $(R E)$ treatments in the Carex meadow. The long dash, dotted and solid regression lines were used for IP, SC and RE treatments, respectively

\section{Discussion}

Impact of shoot clipping and root exclusion on $\mathrm{CH}_{4}$ fluxes

The effects of clipping on $\mathrm{CH}_{4}$ emissions have been reported to vary with water table depth and clipping height above the surface, and are largely species dependent (Schimel 1995; Kelker and Chanton 1997; Ding et al. 2005; Askaer et al. 2011). For example, Askaer et al. (2011) found that clipping all above-ground vegetation decreased $\mathrm{CH}_{4}$ flux by about $70 \%$ as compared to the intact plant system in a Phalaris arundinacea dominated temperate wetland in Denmark. In contrast, Schimel (1995) found that clipping leaf blades significantly increased $\mathrm{CH}_{4}$ flux from a Carex aquatilis site, but not from an Eriophorum angustifolium site in a wet meadow of Alaska. However, we did not find significant difference of $\mathrm{CH}_{4}$ flux rates between shoot clipping and control treatment, which was not consistent with other studies (Ding et al. 2005; Askaer et al. 2011).

$\mathrm{CH}_{4}$ flux depends on the balance between $\mathrm{CH}_{4}$ production, oxidation and transport. Above-ground shoot clippings not only reduced the labile $\mathrm{C}$ into the soil (King and Reeburgh 2002; Ström et al. 2012), but also simultaneously influenced plant mediated $\mathrm{CH}_{4}$ transport and oxidation. For instance, increased $\mathrm{CH}_{4}$ flux due to clipping of Carex aquatilis was attributed to the removal of the resistance to $\mathrm{CH}_{4}$ flow within plant tissues (Schimel 1995). Ding et al. (2005) concluded that Carex lasiocarpa clippings mainly decreased $\mathrm{CH}_{4}$ oxidation, rather than $\mathrm{CH}_{4}$ production, whereas Carex meyeriana clippings led to almost the same effects on $\mathrm{CH}_{4}$ oxidation and production. Although above-ground shoot clipping inevitably decreased the substrate availability for methanogenesis, clipping probably enhanced $\mathrm{CH}_{4}$ transport because the main plant compartment limiting $\mathrm{CH}_{4}$ emissions may not be in the stem of plants, but located at the root-shoot boundary (Kelker and Chanton 1997; Ding et al. 2005). In addition, clipping largely decreased plant photosynthetic activity, leading to less $\mathrm{O}_{2}$ transporting into the rhizosphere and further decreased $\mathrm{CH}_{4}$ oxidation (Ding et al. 2005; Sutton-Grier and Megonigal 2011). Consequently, positive and negative shoot clipping effects on $\mathrm{CH}_{4}$ flux were in balance, resulting in similar $\mathrm{CH}_{4}$ flux rates of shoot clippings and control treatments. This balance may only be relevant for conditions without standing water, as $\mathrm{CH}_{4}$ emissions significantly decreased when shoots were clipped below the water surface (Kelker and Chanton 1997; Ding et al. 2005). Additionally, when no standing water occurs and there is a relatively low water table depth and low soil moisture, typical gas diffusion is not hindered and may prevail over plant-mediated transport. In other words, the role of the plant-mediated gas transport pathway might be weakened under these conditions. This may be another possible reason for the non-significant difference of $\mathrm{CH}_{4}$ fluxes between shoot clippings and control treatments.

In this study, significant positive correlations between $\mathrm{CH}_{4}$ flux and total plant biomass supported our hypothesis that the presence of Carex could enhance $\mathrm{CH}_{4}$ flux in this subtropical wetland. However, $\mathrm{CH}_{4}$ flux was not significantly related to the above-ground biomass, likely because shoot clippings did not significantly alter the $\mathrm{CH}_{4}$ flux rate (Fig. 3a). This suggests that below-ground roots mainly contributed to the plant mediated enhancement in $\mathrm{CH}_{4}$ fluxes during drawdown periods. This was further confirmed by the relationship between $\mathrm{CH}_{4}$ flux and below-ground biomass (Fig. 3b). Both control and shoot clipping treatments showed significant positive correlations between $\mathrm{CH}_{4}$ flux and below-ground biomass, (rather than total biomass) and changes in below-ground biomass could explain $37 \%$ and $44 \%$ of the variation in $\mathrm{CH}_{4}$ fluxes from control and shoot clipping treatments, respectively (Fig. 3b). Owing to the restriction of the trenching method, dead roots were certainly inside the root exclusion plots, and may have contributed to $\mathrm{CH}_{4}$ production. To our knowledge, previous studies have not assessed this impact. Although the effect of 

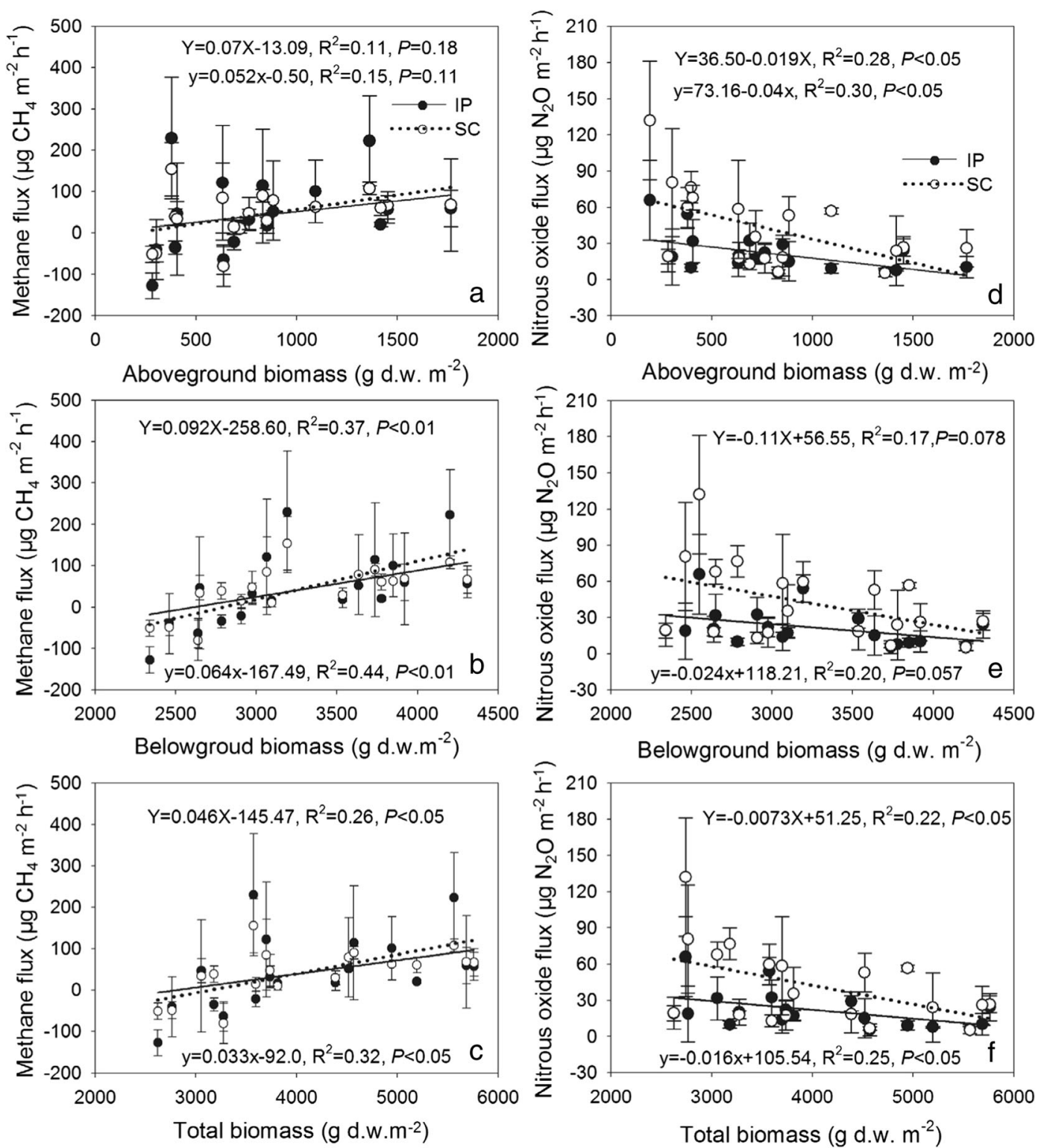

Fig. 3 Effects of biomass on $\mathrm{CH}_{4}(\mathbf{a}, \mathbf{b}, \mathbf{c})$ and $\mathrm{N}_{2} \mathrm{O}(\mathbf{d}, \mathbf{e}, \mathbf{f})$ fluxes. The relation between biomass and fluxes was described using $\mathrm{Y}=\mathrm{aX}+\mathrm{b}$ for intact plants treatments $(I P)$ and $\mathrm{y}=\mathrm{ax}+\mathrm{b}$ for

decomposing roots may not be eliminated, it should be less important with time (Ewel et al. 1987; Bowden et al. 1993; Hanson et al. 2000; Zhou et al. 2007). According to our previous study (Hu et al. 2015), the effects of decomposing roots on soil $\mathrm{CO}_{2}$ efflux are almost negligible after 9 months when the trenching plots were completed. Thus, root exclusion significantly decreased the $\mathrm{CH}_{4}$ flux rate compared to the control treatment $(t=3.0$, $P<0.01)$ when flux data measured after February 2010 was used for the comparison. This result was consistent

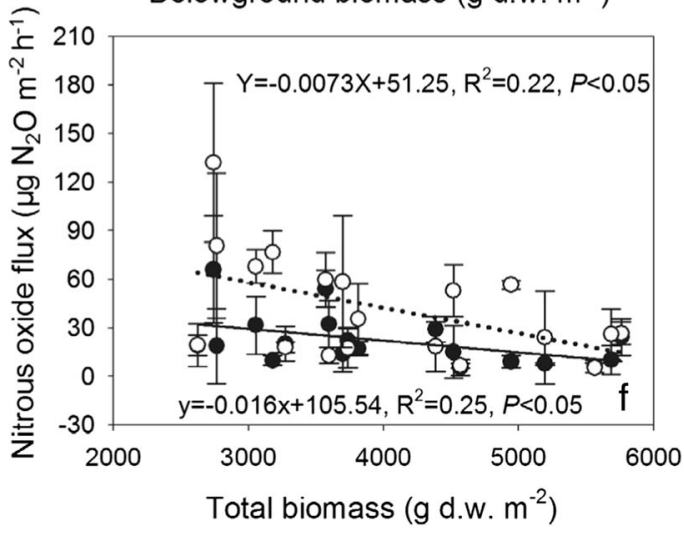

shoot clipping treatments $(S C)$, respectively. The values are presented as mean $\pm \mathrm{SD}$ of three replicates

with previous observations from a vegetation removal study in Alaska (King et al. 1998). When the enormously high flux measured on October 9, 2010 (Fig. 1) was excluded, the mean flux rate of the root exclusion treatment was $-5 \mu \mathrm{g} \mathrm{CH}_{4} \mathrm{~m}^{-2} \mathrm{~h}^{-1}$, and deceased by $116 \%$ in contrast to the control treatment $\left(32 \mu \mathrm{g} \mathrm{CH}_{4} \mathrm{~m}^{-2} \mathrm{~h}^{-1}\right)$. Root exclusion may have stopped the translocation of labile photosynthates, in the form of root exudates, into the rhizosphere, and completely damaged the plant mediated $\mathrm{CH}_{4}$ transport conduit. 
Impact of shoot clipping and root exclusion on $\mathrm{N}_{2} \mathrm{O}$ fluxes

Shoot clippings significantly increased $\mathrm{N}_{2} \mathrm{O}$ fluxes compared to intact plant systems, and the mean $\mathrm{N}_{2} \mathrm{O}$ flux rate of the shoot clipping treatment was double that of the control treatment. With respect to the root exclusion treatment, the mean $\mathrm{N}_{2} \mathrm{O}$ flux rate was almost five times greater than the control treatment. The increased $\mathrm{N}_{2} \mathrm{O}$ emission in the root exclusion treatment might be partly explained by the decomposition of dead roots (Kaiser et al. 1996). However, as mentioned above, it is reasonable to assume that the effect of decomposing roots on $\mathrm{N}$ transformation should gradually decrease. Ross et al. (2001) suggested soil mineral-N concentrations and gross nitrification rates were initially higher in trenched-plots than controls, but were similar in trenched and control treatments after incubation of the soil samples at $25^{\circ} \mathrm{C}$ for 57 days. We found the mean $\mathrm{N}_{2} \mathrm{O}$ flux rate of the root exclusion treatment was still more than five times higher than the control treatment when flux data were measured after February 2010. This indicates that the presence of plants could suppress $\mathrm{N}_{2} \mathrm{O}$ emissions from the Carex meadow, which did not support our hypothesis. This suppression was further demonstrated by the negative correlations between $\mathrm{N}_{2} \mathrm{O}$ fluxes and the above-ground and total biomass (Fig. 3d, f). Contrasting results have been reported on how the presence of plants potentially influences $\mathrm{N}_{2} \mathrm{O}$ fluxes. For instance, no significant alterations on $\mathrm{N}_{2} \mathrm{O}$ emissions by Phalaris arundinacea was reported by Rückauf et al. (2004), whereas the presence of the Phalaris arundinacea increased the annual $\mathrm{N}_{2} \mathrm{O}$ emissions from approximately 65 to $650 \mathrm{~g} \mathrm{~N}_{2} \mathrm{O}$ $\mathrm{N}$ ha $^{-1} \mathrm{yr}^{-1}$ compared to unplanted peat soil in Finland (Hyvoenen et al. 2009). Similar to our study, decreased $\mathrm{N}_{2} \mathrm{O}$ fluxes compared to unplanted controls were also observed in artificial wetlands of Sweden and Canada (Johansson et al. 2003; Maltais-Landry et al. 2009).

Soil $\mathrm{N}_{2} \mathrm{O}$ flux was also linked to its production, consumption and gas transport (Jørgensen et al. 2012). Little is known about the effects of shoot clipping and root exclusion on plant-mediated $\mathrm{N}_{2} \mathrm{O}$ transport, although a few studies have suggested the importance of this transport conduit (Jørgensen et al. 2012; Jørgensen and Elberling 2012). In this study, the role of this gas transport pathway might be weakened due to the relative low water table depth and soil moisture because this mechanism of $\mathrm{N}_{2} \mathrm{O}$ release is generally characterized by high soil water content or saturated soil (Chang et al. 1998). In the Carex meadow of Poyang Lake however, the water table varied from -30 to $-50 \mathrm{~cm}$ in most of the drawdown periods (Hu et al. 2010), and the soil volumetric moisture in the meadow site ranged from $48 \%$ to $65 \%$ (mean of $55 \%$ ). Hence, diffusive transport via soil matrix might out-compete plant-mediated transport in this meadow. More importantly, shoot clipping and root exclusion probably enhanced the availability of mineral $\mathrm{N}$ for microbes because plants cease to take up $\mathrm{NH}_{4}{ }^{+}-\mathrm{N}$ and $\mathrm{NO}_{3}{ }^{-}-\mathrm{N}$ after cutting (Neftel et al. 2000). Therefore, microbe-related $\mathrm{N}_{2} \mathrm{O}$ production prevailed. Similar clipping or cutting effects were also observed in other studies (Rafique et al. 2012; Lavoie et al. 2013).

Both shoot clipping and root exclusion approximately increased $\mathrm{N}_{2} \mathrm{O}$ emissions to the same extent, suggesting shoots and roots might play an equal role in affecting $\mathrm{N}_{2} \mathrm{O}$ flux from the Carex meadow during drawdown periods.

Relations among $\mathrm{CH}_{4}, \mathrm{~N}_{2} \mathrm{O}$ and $\mathrm{CO}_{2}$

In this study, we found that $\mathrm{CH}_{4}$ flux was not significantly related to $\mathrm{N}_{2} \mathrm{O}$ for any of the three treatments (Fig. 2). Hence, our hypothesis on the negative relation between $\mathrm{CH}_{4}$ and $\mathrm{N}_{2} \mathrm{O}$ fluxes was not supported. Several possible explanations exist. $\mathrm{CH}_{4}$ is produced only from anaerobic processes, but $\mathrm{N}_{2} \mathrm{O}$ can result from both aerobic and anaerobic processes (Conrad 1996). Most of the $\mathrm{N}_{2} \mathrm{O}$ emitted into the atmosphere is produced in the upper-most soil layer, whereas $\mathrm{CH}_{4}$ is produced in deeper horizons (Conrad et al. 1983; Conrad 1996). However, we did not measure belowground gas in this study. Furthermore, $\mathrm{CH}_{4}$ and $\mathrm{N}_{2} \mathrm{O}$ can be disproportionately consumed in the soil (Lavoie et al. 2013), and $\mathrm{CH}_{4}$ and $\mathrm{N}_{2} \mathrm{O}$ fluxes can be influenced by numerous environmental variables, including various biotic and abiotic factors (e.g., plant biomass, net primary productivity, water table depth and temperature). Each of them may differ in their roles in $\mathrm{CH}_{4}$ and $\mathrm{N}_{2} \mathrm{O}$ production, consumption and transport. For example, in this study, plants enhanced the $\mathrm{CH}_{4}$ flux, but suppressed the $\mathrm{N}_{2} \mathrm{O}$ flux.

Unlike the $\mathrm{CH}_{4}-\mathrm{N}_{2} \mathrm{O}$ relation, significant positive $\mathrm{CH}_{4}-\mathrm{CO}_{2}$ correlations were observed in all three treatments $\left(\mathrm{CO}_{2}\right.$ data was published in $\mathrm{Hu}$ et al. 2015) (Fig. 4), which was consistent with reported studies (Song et al. 2008; Kato et al. 2011). Changes in $\mathrm{CO}_{2}$ 
Fig. 4 Relationship between $\mathrm{CH}_{4}$ and $\mathrm{CO}_{2}$ fluxes from intact plants $(I P)$, shoot clipping $(S C)$ and root exclusion $(R E)$ treatments. $\mathrm{CH}_{4}$ flux data on June 14, 2009 and October 9, 2010 were not shown in this figure

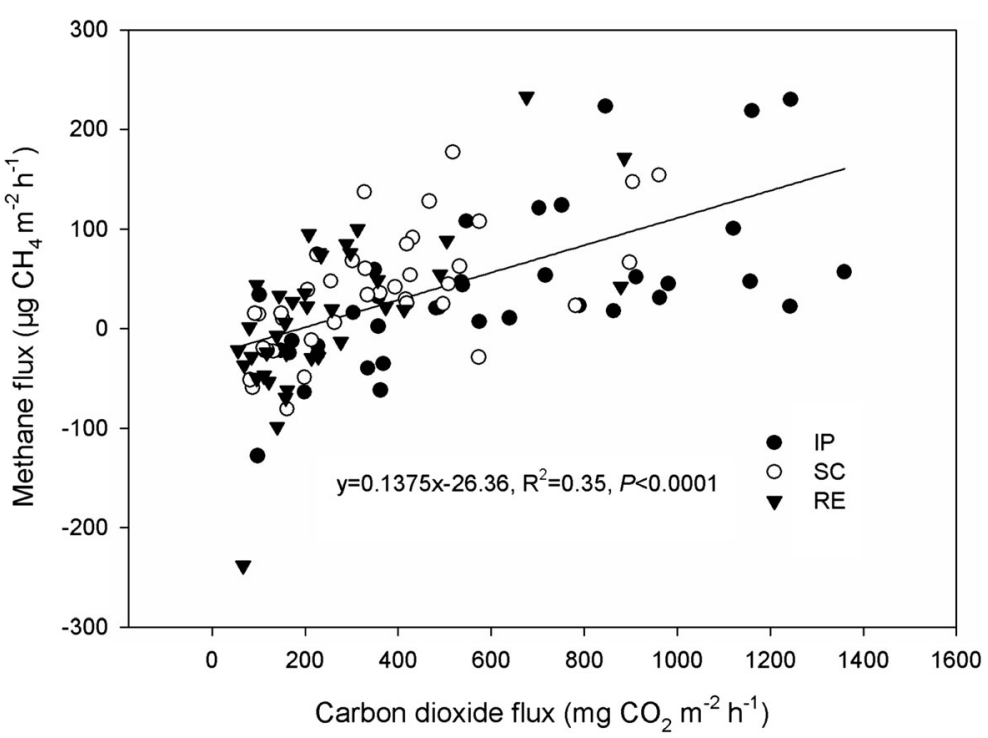

emission could explain $35 \%$ of $\mathrm{CH}_{4}$ variability. This was mainly due to temperature and plant biomass being identical controls of $\mathrm{CO}_{2}$ and $\mathrm{CH}_{4}$ fluxes, and both environmental variables were positively related to them. Although a significant positive $\mathrm{N}_{2} \mathrm{O}-\mathrm{CO}_{2}$ relation was reported in most terrestrial ecosystems (Garcia-Montiel et al. 2002; Xu et al. 2008), no studies have observed the same relation in wetlands. This indicates that distinct microbial processes could be responsible for $\mathrm{N}_{2} \mathrm{O}$ production in terrestrial ecosystems and wetlands. Significant positive $\mathrm{N}_{2} \mathrm{O}-\mathrm{CO}_{2}$ relations reflect that nitrification could be a dominant pathway to produce $\mathrm{N}_{2} \mathrm{O}$ in terrestrial ecosystems where there is high $\mathrm{O}_{2}$ availability. On the contrary, $\mathrm{O}_{2}$ availability is very low in wetlands due to high water contents. Consequently, denitrification is a dominant pathway to produce $\mathrm{N}_{2} \mathrm{O}$ in wetlands, probably leading to insignificant $\mathrm{N}_{2} \mathrm{O}-\mathrm{CO}_{2}$ correlations. Such insignificant correlations were also observed at our meadow site due to high soil moisture. However, this still needs further investigations.

$\mathrm{CH}_{4}$ and $\mathrm{N}_{2} \mathrm{O}$ emissions during drawdown periods

The littoral zones of lakes have been regarded as hotspots of $\mathrm{CH}_{4}$ and $\mathrm{N}_{2} \mathrm{O}$ emissions (Juutinen et al. 2003a; Wang et al. 2006a, 2006b; Chen et al. 2009). For instance, in the boreal Lake Kevätön in Finland, the littoral zone occupied $26 \%$ of the lake area but was estimated to account for most of the $\mathrm{N}_{2} \mathrm{O}$ emissions from the lake (Huttunen et al. 2003). Similarly, in the subtropical Meiliang Bay, Taihu Lake, the littoral zones only accounted for $5.4 \%$ of the total bay area, but contributed about $43.6 \%$ of total $\mathrm{N}_{2} \mathrm{O}$ emissions of the bay (Wang et al. 2006b). $\mathrm{CH}_{4}$ and $\mathrm{N}_{2} \mathrm{O}$ emissions from littoral zones of lakes are largely dependent on the vegetation zone and differ amongst climate zones
Table 2 Net primary productivity, net ecosystem production, soil $\mathrm{CO}_{2}, \mathrm{CH}_{4}$ and $\mathrm{N}_{2} \mathrm{O}$ from the Carex meadow of Poyang Lake during drawdown and flood periods in 2010. The values were presented as mean $\pm \mathrm{SD}$ of three replicates

\begin{tabular}{llll}
\hline Properties & Drawdown periods $(195 \mathrm{~d})$ & Flood periods $(170 \mathrm{~d})$ & Total \\
\hline $\mathrm{CO}_{2}\left(\mathrm{~g} \mathrm{CO}_{2} \mathrm{~m}^{-2}\right)$ & $906 \pm 403$ & $320 \pm 105$ & $1226 \pm 508$ \\
$\mathrm{CH}_{4}\left(\mathrm{~g} \mathrm{CH}_{4} \mathrm{~m}^{-2}\right)$ & $3 \pm 2$ & $18 \pm 4$ & $21 \pm 6$ \\
$\mathrm{~N}_{2} \mathrm{O}\left(\mathrm{mg} \mathrm{N}_{2} \mathrm{O} \mathrm{m}^{-2}\right)$ & $100 \pm 60$ & $8 \pm 25$ & $108 \pm 85$ \\
$\mathrm{CH}_{4}$ e $\left(\mathrm{g} \mathrm{CO}_{2} \mathrm{eq} \mathrm{m}^{-2}\right)$ & $84 \pm 56$ & $504 \pm 112$ & $588 \pm 168$ \\
$\mathrm{~N}_{2} \mathrm{O} \_\mathrm{e}\left(\mathrm{g} \mathrm{CO}_{2} \mathrm{eq} \mathrm{m}^{-2}\right)$ & $27 \pm 16$ & $2 \pm 7$ & $29 \pm 23$ \\
$\mathrm{NPP}\left(\mathrm{g} \mathrm{C} \mathrm{m}^{-2}\right)$ & $2005 \pm 375$ & 0 & $2005 \pm 375$ \\
$\mathrm{NEP}\left(\mathrm{g} \mathrm{C} \mathrm{m}^{-2}\right)$ & $1758 \pm 265$ & $-87 \pm 29$ & $1671 \pm 294$ \\
\hline
\end{tabular}


(Table 1). As shown in Table 1, $\mathrm{CH}_{4}$ emissions from the littoral Carex meadow of Poyang Lake during dryingwetting transition periods were comparable to other littoral wetlands, but were much lower during drying periods. This was mainly due to that the drying periods in our site were characterized by no standing water and relatively low soil moisture. In addition, our $\mathrm{N}_{2} \mathrm{O}$ flux rate was much lower than those of Tibetan Huahu Lake and subtropical Taihu Lake, likely because of lake trophic differences (Wang et al. 2006a; Chen et al. 2009).

In the same Carex meadow, $\mathrm{CH}_{4}$ emissions during summer flood periods from 2009 to 2010 ranged from 2637 to $5625 \mu \mathrm{g} \mathrm{CH}_{4} \mathrm{~m}^{-2} \mathrm{~h}^{-1}$ (mean of $4426 \mu \mathrm{g} \mathrm{CH}_{4}$ $\mathrm{m}^{-2} \mathrm{~h}^{-1}$ ) (Hu et al. 2011), and $\mathrm{N}_{2} \mathrm{O}$ emission rate varied from -13 to $9 \mu \mathrm{g} \mathrm{N}_{2} \mathrm{O} \mathrm{m}^{-2} \mathrm{~h}^{-1}$ (mean of $2 \mu \mathrm{g} \mathrm{N} \mathrm{N}_{2} \mathrm{O}$ $\mathrm{m}^{-2} \mathrm{~h}^{-1}$ ) (unpublished data). Meanwhile, the mean soil microbial respiration rate was $194 \mathrm{mg} \mathrm{CO} \mathrm{m}^{-2} \mathrm{~h}^{-1}$ during drawdown periods (Hu et al. 2015), but $78 \mathrm{mg}$ $\mathrm{CO}_{2} \mathrm{~m}^{-2} \mathrm{~h}^{-1}$ during flood periods (unpublished data). Therefore, we estimated annual greenhouse gas emissions from the Carex meadow in 2010 (Table 2). There were large annual variations of $\mathrm{CH}_{4}$ and $\mathrm{N}_{2} \mathrm{O}$ emissions. Drawdown periods accounted for about $14 \%$ of the total $\mathrm{CH}_{4}$ emission, and $93 \%$ of total $\mathrm{N}_{2} \mathrm{O}$ emission in 2010 , whereas, the flood periods was $86 \%$ and $7 \%$, respectively. Previous studies have suggested that about $3 \%$ to $4 \%$ of net ecosystem production (NEP) is emitted back to the atmosphere as $\mathrm{CH}_{4}$ (Whiting and Chanton 1993; Bellisario et al. 1999). In this study, however, $\mathrm{CH}_{4}$ emissions during drawdown periods were relatively low and accounted for less than $1 \%$ of the annual carbon assimilation, which was consistent with Askaer et al. (2011). This could be partly explained by a strong $\mathrm{C}$ sink due to the double growing season of the Carex meadow during drawdown periods (Hu et al. 2015). In addition, the meadow soil was not covered by standing water during the drawdown periods, resulting in low $\mathrm{CH}_{4}$ emissions.

$\mathrm{CH}_{4}$ and $\mathrm{N}_{2} \mathrm{O}$ have 28 and 265 times larger global warming potentials (GWP) than $\mathrm{CO}_{2}$ over a 100 -year timescale, respectively (IPCC 2013). When the GWP of $\mathrm{CH}_{4}$ and $\mathrm{N}_{2} \mathrm{O}$ are taken into account, many studies have suggested the wetland $\mathrm{C}$ sink could be largely offset, and potentially turn into sources of atmospheric radiative forcing (Whiting and Chanton 2001; Friborg et al. 2003; Ding et al. 2013). In the Carex meadow, soil $\mathrm{CO}_{2}$ emission dominated the GHG emissions (Table 2). However, when the GWP was taken into account, $\mathrm{CH}_{4}$ and $\mathrm{N}_{2} \mathrm{O}$ accounted for $11 \%$ of the overall GHG emissions during drawdown periods and $33 \%$ for the whole year in 2010. Hence, it is necessary to integrate $\mathrm{CH}_{4}$ and $\mathrm{N}_{2} \mathrm{O}$ emissions into the assessment of net greenhouse gas effects from the Carex meadow.

\section{Conclusions}

With two-year in situ measurements of $\mathrm{CH}_{4}$ and $\mathrm{N}_{2} \mathrm{O}$ fluxes from a Carex meadow of Poyang Lake during drawdown periods, we conclude that shoot clipping did not significantly alter $\mathrm{CH}_{4}$ flux rates, but root exclusion decreased $\mathrm{CH}_{4}$ flux by $116 \%$ compared to the control. This suggests that roots, rather than shoots, dominated plant-mediated enhancement in $\mathrm{CH}_{4}$ fluxes in this Carex meadow during drawdown periods. Both shoot clipping and root exclusion significantly increased $\mathrm{N}_{2} \mathrm{O}$ fluxes compared to the control, likely due to the increase of mineral $\mathrm{N}$ available for soil microbes. Shoots played an almost equal role as roots in plant-regulated suppression on $\mathrm{N}_{2} \mathrm{O}$ fluxes in this Carex meadow during drawdown periods. There were no significant correlations between $\mathrm{CH}_{4}$ and $\mathrm{N}_{2} \mathrm{O}$ fluxes. Considering GWP, $\mathrm{CH}_{4}$ and $\mathrm{N}_{2} \mathrm{O}$ accounted for $11 \%$ of the overall GHG emissions in the Carex meadow during drawdown periods, but $33 \%$ for the whole year in 2010. Therefore, $\mathrm{CH}_{4}$ and $\mathrm{N}_{2} \mathrm{O}$ fluxes should be considered when $\mathrm{C}$ sinks or sources are evaluated in such subtropical wetlands.

Acknowledgments This study was supported by National Natural Science Foundation of China (Grant No. 31270522 and 40803022) and the Collaborative Innovation Center for Major Ecological Security Issues of Jiangxi Province and Monitoring Implementation (No.JXS-EW-00). The China Scholarship Council sponsored the principal author for his research at the University of Rhode Island.

\section{References}

Askaer L, Elberling B, Friborg T, Jørgensen CJ, Hansen BU (2011) Plant-mediated $\mathrm{CH}_{4}$ transport and $\mathrm{C}$ gas dynamics quantified in-situ in a Phalaris arundinacea-dominant wetland. Plant Soil 343:287-301. doi:10.1007/s11104-0110718-x

Bäckstrand K, Crill PM, Jackowicz-Korczyñski M, Mastepanov M, Christensen TR, Bastviken D (2010) Annual carbon gas budget for a subarctic peatland, northern Sweden. Biogeosciences 7(1):95-108

Bellisario LM, Bubier JL, Moore TR, Chanton JP (1999) Controls on $\mathrm{CH}_{4}$ emissions from a northern peatland. Global Biogeochem Cy 13(1):81-91 
Bernal B, Mitsch WJ (2012) Comparing carbon sequestration in temperate freshwater wetland communities. Glob Chang Biol 18:1636-1647

Bowden RD, Nadelhoffer KJ, Boone RD, Melillo JM, Garrison JB (1993) Contributions of above ground litter, below ground litter, and root respiration to total soil respiration in a temperate mixed hardwood forest. Can J For Res 23:1402-1407

Bridgham SD, Cadillo-Quiroz H, Keller JK, Zhuang QL (2013) Methane emissions from wetlands: biogeochemical, microbial, and modeling perspectives from local to global scales. Glob Chang Biol 19(5):1325-1346

Cavieres LA, Badano EI (2009) Do facilitative interactions increase species richness at the entire community level? J Ecol 97:1181-1191

Chang C, Janzen HH, Nakonechny EM, Cho CM (1998) Nitrous oxide emission through plants. Soil Sci Soc Am J 62(1):3538

Chen H, Wu N, Yao SP, Gao YH, Zhu D, Wang YF, Yuan XZ (2009) High methane emissions from a littoral zone on the Qinghai-Tibetan plateau. Atmos Environ 43(32):4995-5000

Chen H, Wang M, Wu N, Wang YF, Zhu D, Gao YH, Peng CH (2011) Nitrous oxide fluxes from the littoral zone of a lake on the Qinghai-Tibetan plateau. Environ Monit Assess 182(1-4): 545-553

Conrad R (1996) Soil microorganisms as controllers of atmospheric trace gases $\left(\mathrm{H}_{2}, \mathrm{CO}, \mathrm{CH}_{4}, \mathrm{OCS}, \mathrm{N}_{2} \mathrm{O}\right.$, and $\left.\mathrm{NO}\right)$. Microbiol Rev 60(4):609-640

Conrad R, Seiler W, Bunse G (1983) Factors influencing the loss of fertilizer nitrogen into the atmosphere as $\mathrm{N}_{2} \mathrm{O}$. J Geophys Res 88:6709-6718

Ding WX, Cai ZC, Tsuruta H (2005) Plant species effects on methane emissions from freshwater marshes. Atmos Environ 39(18):3199-3207

Ding W, Zhu RB, Ma DW, Xu H (2013) Summertime fluxes of $\mathrm{N}_{2} \mathrm{O}, \mathrm{CH}_{4}$ and $\mathrm{CO}_{2}$ from the littoral zone of lake daming, east Antarctica: effects of environmental conditions. Antarct Sci 25(6):752-762

Dong M (1997) Observation and analysis methods for terrestrial biological community. Chinese Standard Press

Dorodnikov M, Knorr KH, Kuzyakov Y, Wilmking M (2011) Plant-mediated $\mathrm{CH}_{4}$ transport and contribution of photosynthates to methanogenesis at a boreal mire: a ${ }^{14} \mathrm{C}$ pulselabeling study. Biogeosciences 8(8):2365-2375

Ewel KC, Cropper Jr WP, Gholz HL (1987) Soil CO $\mathrm{CO}_{2}$ evolution in Florida slash pine plantations. II. Importance of root respiration. Can J For Res 17:330-333

Forster P, Ramaswamy V, Artaxo P, et al. (2007) Changes in atmospheric constituents and in radiative forcing. In: Solomon S, Qin D, Manning M, Chen Z (eds) Climate change 2007: the physical science basis. Contribution of working group I to the fourth assessment report of the intergovernmental panel on climate change. Cambridge University Press, Cambridge

Friborg T, Soegaard H, Christensen TR, Lloyd CR, Panikov NS (2003) Siberian wetlands: where a sink is a source. Geophys Res Lett 30(21). doi:10.1029/2003GL017797

Garcia-Montiel D, Melillo J, Steudler P, Neill C, Feigl B, Cerri C (2002) Relationship between $\mathrm{N}_{2} \mathrm{O}$ and $\mathrm{CO}_{2}$ emissions from the Amazon Basin. Geophys Res Lett 29:GB3012. doi:10. 1029/2002GL013830
Hanson PJ, Edwards NT, Garten CT, Andrews JA (2000) Separating root and soil microbial contributions to soil respiration: a review of methods and observations. Biogeochemistry 48:115-146

Hedin LO, von Fischer JC, Ostrom NE, Kennedy BP, Brown MG, Robertson GP (1998) Thermodynamics constraints on nitrogen transformations and other biogeochemical processes at soil-stream interfaces. Ecology 79(2):684-703

Hu ZP, Ge G, Liu CL, Chen FS, Li S (2010) Structure of Poyang Lake wetland plants ecosystem and influence of lake water level for the structure. Resources and Environment in the Yangtze Basin 19(6):597-605(In Chinese)

Hu QW, Zhu LL, Xing RX, Yao B, Hu BH (2011) Methane emission from a carex-dominated wetland in Poyang Lake. Acta Ecol Sin 31(17):4851-4857(In Chinese)

Hu QW, Wu Q, Yao B, Xu XL (2015) Ecosystem respiration and its components from a carex meadow of Poyang Lake during the drawdown period. Atmos Environ 100:124-132

Huttunen JT, Juutinen S, Alm J, Larmola T, Hammar T, Silvola J, Martikainen PJ (2003) Nitrous oxide flux to the atmosphere from the littoral zone of a boreal lake. J Geophys Res 108(D14):4421. doi:10.1029/2002JD002989

Hyvoenen NP, Huttunen JT, Shurpali NJ, Tavi NM, Repo ME, Martikainen PJ (2009) Fluxes of nitrous oxide and methane on an abandoned peat extraction site: effect of reed canary grass cultivation. Bioresour Technol 100:4723-4730

IPCC, 2013, Climate Change 2013: The Physical Science Basis. Contribution of Working Group I to the Fifth Assessment Report of the Intergovernmental Panel on Climate Change [Stocker TF Qin D, Plattner GK, Tignor M, Allen SK, Boschung J, Nauels A, Xia Y, Bex V, Midgley PM (eds.)]. Cambridge University Press, Cambridge

Johansson AE, Klemedtsson ÅK, Klemedtsson L, Svensson BH (2003) Nitrous oxide exchanges with the atmosphere of a constructed wetland treating wastewater- parameters and implications for emission factors. Tellus B 55(3):737-750

Jørgensen CJ, Elberling B (2012) Effects of flooding-induced $\mathrm{N}_{2} \mathrm{O}$ production, consumption and emission dynamics on the annual $\mathrm{N}_{2} \mathrm{O}$ emission budget in wetland soil. Soil Biol Biochem 53:9-17

Jørgensen CJ, Struwe S, Elberling B (2012) Temporal trends in $\mathrm{N}_{2} \mathrm{O}$ flux dynamics in a Danish wetland-effects of plantmediated gas transport of $\mathrm{N}_{2} \mathrm{O}$ and $\mathrm{O}_{2}$ following changes in water level and soil mineral-N availability. Glob Chang Biol 18(1):210-222

Juutinen S, Alm J, Larmola T, Huttunen JT, Morero M, Martikainen PJ, Silvola J (2003a) Major implication of the littoral zone for methane release from boreal lakes. Global Biogeochem CY 17(4)

Juutinen S, Alm J, Larmola T, Huttunen JT, Morero M, Saarnio S, Martikainen PJ, Silvola J (2003b) Methane $\left(\mathrm{CH}_{4}\right)$ release from littoral wetlands of boreal lakes during an extended flooding period. Glob Chang Biol 9(3):413-424

Kaiser EA, Eiland F, Germon C, et al. (1996) What predicts nitrous oxide emissions and denitrification N-loss from European soils? Z Pflanzenernähr Bodenkd 159(6):541-547

Kankaala P, Käki T, Mäkelä S, Ojala A, Pajunen H, Arvola L (2005) Methane efflux in relation to plant biomass and sediment characteristics in stands of three common emergent macrophytes in boreal mesoeutrophic lakes. Glob Chang Biol 11(1):145-153 
Kao-Kniffin J, Freyre DS, Balser TC (2010) Methane dynamics across wetland plant species. Aquat Bot 93(2):107-113

Kato T, Hirota M, Tang Y, Wada E (2011) Spatial variability of $\mathrm{CH}_{4}$ and $\mathrm{N}_{2} \mathrm{O}$ fluxes in alpine ecosystems on the Qinghai Tibetan plateau. Atmos Environ 45(31):5632-5639

Kelker D, Chanton J (1997) The effect of clipping on methane emissions from carex. Biogeochemistry 39(1):37-44

King JY, Reeburgh WS (2002) A pulse-labeling experiment to determine the contribution of recent plant photosynthates to net methane emission in Arctic wet sedge tundra. Soil Biol Biochem 34(2):173-180

King JY, Reeburgh WS, Regli SK (1998) Methane emission and transport by Arctic sedges in Alaska: results of a vegetation removal experiment. J Geophys Res 103(D22):29083-29092

Kuzyakov Y (2006) Sources of $\mathrm{CO}_{2}$ efflux from soil and review of partitioning methods. Soil Biol Biochem 38(3):425-448

Laanbroek HJ (2010) Methane emission from natural wetlands: interplay between emergent macrophytes and soil microbial processes. A mini-review. Ann Bot 105(1):141-153

Larmola T, Alm J, Juutinen S, Martikainen PJ, Silvola J (2003) Ecosystem $\mathrm{CO}_{2}$ exchange and plant biomass in the littoral zone of a boreal eutrophic lake. Freshw Biol 48:1295-1310

Lavoie M, Kellman L, Risk D (2013) The effects of clear-cutting on soil $\mathrm{CO}_{2}, \mathrm{CH}_{4}$, and $\mathrm{N}_{2} \mathrm{O}$ flux, storage and concentration in two Atlantic temperate forests in Nova Scotia, Canada. For Ecol Manag 304:355-369

Liu XZ, Fan SB, Hu BH (2006) Comprehensive and scientific survey of Jiangxi nanjishan wetland nature reserve. Chinese Forestry Press, Beijing(In Chinese)

Liu YS, Zhu RB, Ma DW, Xu H, Luo YH, Huang T, Sun LG (2011) Temporal and spatial variations of nitrous oxide fluxes from the littoral zones of three alga-rich lakes in coastal Antarctica. Atmos Environ 45(7):1464-1475

Maltais-Landry G, Maranger R, Brisson J, Chazarenc F (2009) Greenhouse gas production and efficiency of planted and artificially aerated constructed wetlands. Environ Pollut 157(3):748-754

Marotta H, Pinho L, Gudasz C, Bastviken D, Tranvik LJ, EnrichPrast A (2014) Greenhouse gas production in low-latitude lake sediments responds strongly to warming. Nat Clim Chang 4:467-470

Neftel A, Blatter A, Schmid M, Lehmann B, Tarakanov SV (2000) An experimental determination of the scale length of $\mathrm{N}_{2} \mathrm{O}$ in the soil of grassland. J Geophys Res 105:12095-12103

Rafique R, Anex R, Hennessy D, Kiely G (2012) What are the impacts of grazing and cutting events on the $\mathrm{N}_{2} \mathrm{O}$ dynamics in humid temperate Grassland? Geoderma 181:36-44

Robertson GP, Coleman DC, Bledsoe CS, Sollins P (1999) Standard soil methods for long-term ecological research. Oxford University Press

Ross DJ, Scott NA, Tate KR, Rodda NJ, Townsend JA (2001) Root effects on soil carbon and nitrogen cycling in a Pinus radiata D. Don plantation on a coastal sand. Aust J Soil Res 39(5):1027-1039

Rückauf U, Augustin J, Russow R, Merbach W (2004) Nitrate removal from drained and reflooded fen soils affected by soil $\mathrm{N}$ transformation processes and plant uptake. Soil Biol Biochem 36(1):77-90
Schimel JP (1995) Plant transport and methane production as controls on methane flux from Arctic wet meadow tundra. Biogeochemistry 28:183-200

Song CC, Zhang JB, Wang YY, Wang YS, Zhao ZC (2008) Emission of $\mathrm{CO}_{2}, \mathrm{CH}_{4}$ and $\mathrm{N}_{2} \mathrm{O}$ from freshwater marsh in northeastern of China. J Environ Manag 88:428-436

Ström L, Tagesson T, Mastepanov M, Christensen TR (2012) Presence of Eriophorum scheuchzeri enhances substrate availability and methane emission in an Arctic wetland. Soil Biol Biochem 45:61-70

Sutton-Grier AE, Megonigal JP (2011) Plant species traits regulate methane production in freshwater wetland soils. Soil Biol Biochem 43(2):413-420

Wang YS, Wang YH (2003) Quick measurement of $\mathrm{CH}_{4}, \mathrm{CO}_{2}$ and $\mathrm{N}_{2} \mathrm{O}$ emissions from short-plant ecosystems. Adv Atmos Sci 20:842-844

Wang HJ, Lu JW, Wang WD, Yang LY, Yin CQ (2006a) Methane fluxes from the littoral zone of hypereutrophic taihu lake, China. J Geophys Res 111(D17109). doi:10.1029/ 2005JD006864

Wang HJ, Wang WD, Yin CQ, Wang YC, Lu JW (2006b) Littoral zones as the "hotspots" of nitrous oxide $\left(\mathrm{N}_{2} \mathrm{O}\right)$ emission in a hyper-eutrophic lake in China. Atmos Environ 40(28):55225527

Wang YH, Inamori R, Kong HN, Xu KQ, Inamori Y, Kondo T, Zhang JX (2008) Nitrous oxide emission from polyculture constructed wetlands: effect of plant species. Environ Pollut 152:351-360

Whiting GJ, Chanton JP (1992) Plant-dependent $\mathrm{CH}_{4}$ emission in a subarctic Canadian fen. Global Biogeochem Cy 6(3):225231

Whiting GJ, Chanton JP (1993) Primary production control of methane emissions from wetlands. Nature 364:794-795

Whiting GJ, Chanton JP (2001) Greenhouse carbon balance of wetlands: methane emission versus carbon sequestration. Tellus B 53(5):521-528

Wickland KP, Striegl RG, Mast MA, Clow DW (2001) Carbon gas exchange at a southern rocky mountain wetland, 1996-1998. Global Biogeochem Cy 15(2):321-335

$\mathrm{Xu}$ XF, Tian HQ, Hui DF (2008) Convergence in the relationship of $\mathrm{CO}_{2}$ and $\mathrm{N}_{2} \mathrm{O}$ exchanges between soil and atmosphere within terrestrial ecosystems. Glob Chang Biol 14(7):16511660

Zhang Q, Li L, Wang YG, Werner AD, Xin P, Jiang T, Barry DA (2012) Has the three-gorges dam made the Poyang Lake wetlands wetter and drier? Geophys Res lett 39 (20) doi:10. 1029/2012GL053431

Zhou XH, Wan SQ, Luo YQ (2007) Source components and interannual variability of soil $\mathrm{CO}_{2}$ efflux under experimental warming and clipping in a grassland ecosystem. Glob Chang Biol 13:761-775

Zhu RB, Liu YS, Xu H, Huang T, Sun JJ, Ma ED, Sun LG (2010) Carbon dioxide and methane fluxes in the littoral zones of two lakes, east Antarctica. Atmos Environ 44(3):304-311

Zhuang QL, Lu YY, Chen M (2012) An inventory of global $\mathrm{N}_{2} \mathrm{O}$ emissions from the soils of natural terrestrial ecosystems. Atmos Environ 47:66-75 